\title{
Different Forms of Execution of Criminal Decisions as a Key Element in Criminal Justice
}

\author{
Ph.D. Nikolin Hasani \\ University "Ismail Qemali" Vlore, Albania, Faculty of Human Sciences, Department of Law \\ hasani.nikolin@yahoo.com
}

Doi:10.5901/ajis.2015.v4n3s1p251

Abstract

There are different definitions for the criminal justice system. The one we are referring to in this paper is the one which describes it as an intricate machine, consisting of many parts, each of which must be properly aligned and connected to function properly. As far as increase the ability of the staff of the responsible agency for the punishment of the criminals, the result will be a more effective in the system for detecting, apprehending, investigating, prosecuting, of a country. The process of emplacing the violated justice and giving justice to the right person at the right time is presented as one of the main challenges that come before each legal and democratic state.

Keywords: criminal decision, criminal justice, execution.

\section{Introduction}

How is defined a crime? Different authors agree that a crime consist in any activity that result in the law break. This definition is not so helpful for us to understand the complexity of classifying criminal behavior.

An important element in determining the level of democracy of a country is the indicator how the law, authorities, and representatives of the State guarantee these rights but also the effectiveness of their implementation in everyday life. So how much takes care state for the protection and inviolability of the rights of its citizens, should be considered with special attention how much are executed the final criminal judgments in a state. The value of this moment as the last link in the examination of a criminal case is clearly understood, because only after this moment we can say that the violated justice has been emplaced.

\section{Execution of Criminal Decision by the Criminal Code}

Criminal Code is presented as the basis for the establishment and implementation of criminal justice. It defines the actions and omissions that are considered illegal and punishable, and convictions and other measures taken against authors of criminal offenses.

One of the most important articles in the field of enforcement of criminal punishment especially the one to imprisonment, is Article 57, which stipulates the calculation of detention as a day and a half in prison. But this situation is problematic in the case for the convicted person even though there is a final judicial decision he continues to perform the punishment in the pretrial detention facilities by violating thus a number of rights so that the person would have by being present in the status of convicted person and not any longer that of the accused.

Article 64 of the Code provides for release on parole, while a special value have also the articles that provide for alternatives to sentencing, treatment of specific groups of convicted persons, protection of minors, victims or rehabilitation measures. All these provisions are an important component that testifies to the peaceful character of the criminal law in general and the Criminal Code but should consider the fact that their use and execution in the judicial decisions gives ground on discussion, especially when compared to analogous cases in western countries. One of the elements that further emphasized the peaceful character of criminal justice was the abolition of the capital punishment. Code bisedes the humanity is accompanied by the duality of severity. It provides severe penalties as 25 years imprisonment or life imprisonment. So the code as a base document for the entire justice system has essential value in determining the fundamental bases on which will develop the executions of judicial decisions since at the time of commencement of execution of until the rehabilitation and re-integration of convicted person in society. 


\section{Execution of Criminal Decision under Criminal Procedure Code}

Criminal Procedure Code has undergone continuous changes since its adoption until now aiming at adapting to perfection with constitutional requirements and norms of international law. This Code has a special importance in relation to the execution of criminal decisions because it is the one that determines the totality of entities that participate, the totality of the rights and principles to be followed, procedures and terms to appeal or recourse etc., the totality of the steps of procedural norms to be followed from the moment of decision making until its execution. It is this code that defines the totality of principles that should be adhered like: Adhering procedural norms, the principle of independence of the judiciary, the principle of presumption of innocence, the legal regulation of restriction of person liberty and the prohibition of torture, guarantee the protection, prevention the trial twice for the same act or omission, the principle of the use of the Albanian language, that of restoring the right etc.. ${ }^{1}$.

Any decision, any kind of punishment or sanction contains must first become final in order to be put into execution.

Execution of criminal decisions means implementation of a final decision containing sanction and implementation of decisions with immediate execution. Such decisions are presented in the form of criminal decisions containing guilt, criminal decisions that exclude the defendant from punishment, criminal decisions that provide for termination of the trial, when arrested in flagrance or detention are illegal, when to an arrested person court renders decisions equal to or smaller than the detention time, decisions that provide for sequestration like a temporary measure, criminal decisions providing for as punishment to imprisonment and finally approve the prosecutor's request for arrest security measure.

It is evidenced like an exceptional case, that of immediate execution and issuance of the order of execution, the issuance of the order of execution by the prosecutor (without become still final) due to judicial mistakes in cases where the court:

- condemns the person with the time of detention and in enacting clause of the decision not orders immediate release of convicted person in the courtroom

- condemns the person some days more than time of detention

In these two cases, the court makes available to the prosecutor the decision or its shortening and it is the prosecutor who issues the order of immediate execution of the decision. Finally we can say that the decision becomes final when it is not to be filed within the legal time limits and when the high court upholds the decision appealed.

\section{Execution of Supplementary Punishment ${ }^{2}$}

Supplementary punishments after serving the main sentence are executed. Execution order the prosecutor sends the body responsible for carrying out the action that contains punishment. Liability for acts contrary to the decision.

The convicted person or body charged with the execution of punishment when performing actions contrary to the decision of the court, have a responsibility under Article 321 of the Criminal Code. State bodies, which conclude action contrary to the decision of the court, are obliged to inform the prosecutor, who also appointed by the court shall proceed according to the law. Prohibition to drive Order Police authorities, according to the order of the prosecutor make notes in folders and withdraw the convicted person the license as long as the court ruled. Prohibition of stay: On the execution order, the State Police act in order to prevent the entry of the convicted person at a certain administrative units and his removal when he is found in them. In implementing this measure of order police authorities in the respective territories to perform actions such as seeking person, as long as they do not contradict with the law. When a convicted person at the time of execution of the decision is a single parent with minor child and when the convicted person is unable to maintain him, through council custody made settling child.

Expulsion from the territory: sentence of expulsion from the territory is executed by the convicted person within the term preset in the execution order; otherwise the rules of execution are forced. When the convicted has had the main conviction the imprisonment, the expulsion from the territory is executed by police of the prisons immediately upon completion of main sentence of the convicted person. When the convicted person cannot return to his country, is or in another state, the prosecutor is supposed to provide entering in the convicted country's or visa, otherwise he should submit a request to amend the supplementary sentence. In any case to foreign citizens convicted, the prosecutor through

\footnotetext{
1 See Articles 2-9 of the Code of Criminal Procedures of RA

2 See Kurti, S. (2015). The Accessory Penalties for Individuals and their Execution According to the Albanian Legislation. Academic Journal of Interdisciplinary Studies, 2015.
} 
the Ministry of Justice informs the Ministry of Foreign Affairs on the order of execution of this sentence.

The execution of the sentence of forfeiture: criminal decisions that predict seizure of assets and the benefits derived from criminal acts carried out by the competent enforcement authority under the provisions of the Code of Civil Procedure for compulsory execution. The bailiff in the execution of the decision is not limited to objects seized, but all objects and benefits provided expressly in the court decision. Prohibition of the exercise of public duties. Supplementary punishment of prohibition to exercise public office or public service is implemented by the body that appointed or which has entered the labor relations the convicted person, with appropriate removal, observing the relevant legal rules. When the labor relations are created by selection, the decision is executed by the competent authority. When public service assignments is conditional upon licensing, is executed by the decision which grants the license. Prohibition of the exercise of an activity or skill. The body that is responsible for granting permission or authorization to practice a certain activity or skill is required on the basis of the prosecutor's order to remove a person convicted of certain documents for the time in the court decision and notifies the financial competent body.

Deprivation of the right to exercise leading duties. Deprivation of the right to exercise leading tasks, to juridical persons, made by the body that has such a right under the statute or the relevant rules and notify the competent financial authority. Liability for the publication of the decision. In the execution of this decision, the prosecutor makes available to convicted the full text or its extract as defined in court. The convicted is obliged to publish, at his own expense, in one or several media bodies, in the time and manner specified in the decision and, when there are obstacles, requiring the intervention of the prosecutor. Where the court explicitly defined, objects to reasonable cause or publication in the body is impossible, the prosecutor asks the court changing decision. On the contrary prosecutor determines the way of publication.

\section{Execution of Decision to Stay Home}

If the court decides severing the punishment given, to stay home, provided for subsection "a" of Article 59 of the Penal Code for execution immediately sends to the prosecutor the decision, and, if it is held in an institution of execution of criminal decisions, also to the Directorate of this institution. Court is the institution, which according to reports of parole service decides how to proceed with further ways of serving that sentence to the convict by the institution and that this decision sends to other organs.

\section{Serving the Sentence in the Institutions of their Suffering}

In Albania there are these institutions of serving the sentence:

- high security prisons

- common security prisons

- lower security prisons

- special Institutions of serving the punishment.

- institutions of detention

This classification has a special importance as each of the above types of institutions has a special security regime, consequently limiting the rights and freedoms of the people who live in them. International standards require that places where detainees are held, prison buildings and institutions determined to be used for the suffering of convictions meet the requirements for a life as normal as possible and ensure the implementation of programs and activities for severing the sentence and re-integration of the convicted into society.

\section{Role of the Prosecutor in Execution of Criminal Decisions}

One of the most important entities, which has the task of powering the procedure of execution of criminal decisions is the prosecutor. The prosecutor ${ }^{3}$ and all other bodies that execute criminal decisions, including the courts, the judicial police, state police, military police, authorities of judicial Bailiff, state bodies or other legal state or private entities, are legally obligated to exercise correctly the powers respecting the rights, honor and dignity of persons arrested, detained or

${ }^{3}$ Article 463 of the Criminal Procedure Code and Articles 09/12/52 of the Law No. 8331, dated 21.04.1998 "On the execution of criminal decisions" 
convicted. These entities have the obligation to notify the prosecutor, the facts and circumstances affecting the manner and time of execution of criminal decision, and for the commencement and completions of the execution, manner of implementation, the violated rights etc.

However it should be noted that the prosecutor's duties and responsibilities are especially important at this stage, because the prosecutor is obliged to take all measures for the execution of decisions in accordance with court orders and requirements of the law, to control the regularity of the execution of decisions, to intervene in various competent bodies or file requests to the court, to restore law and violated rights, and to put offenders to disciplinary responsibility and criminal liability.

Very important are the preliminary actions of the prosecutor, such as the right to request the court the union of convictions when the convicted person has to serve more than one sentence, or the rights and duties and that on the basis of the decision of court and criteria "on the rights and treatment of convicted persons to imprisonment" to determine the type of institution where the convicted person will serve his sentence. When the prosecutor has evidence that is necessary to set the convicted person in specific institutions, he orders the medical check of the convicted. The prosecutor issued the order of execution that is a procedural act on the basis of which he starts the initiation of the execution of criminal decisions. This order is sent to the police where the convicted person resides. When the convicted person is detained order is sent to the place where the person convicted is. When the court decides by decision to suspend the execution of the sentence to imprisonment, the prosecutor has the right when he determines that the person convicted does not conduct or acts contrary to the decision of the court he submits a request for revocation of the sentence 4 .

\section{Execution of Decision "Activities of Public Interest"}

When the court decides to suspend the execution of decision to imprisonment by the consent of the convicted, its replacement with an obligation to perform unpaid work in the public interest, the respective decision sends immediately prosecutor for the execution of alternative sentencing. It should be remembered that the court reverse the decision to suspend the imprisonment sentence based on good behavior of the convicted reports, which are submitted by the institution where he serves the sentence, compiled by social workers in these institutions and the institution possesses. The next step is to send this decision to the prosecutor, who is bound to implement this decision and immediately contact the parole service, which institution shall follow all other links. The Parole, given the skills and training of the convicted person, designs and develops a program for performing work in the public interest.

\section{Concluding Remarks}

Criminal Code is presented as the basis for the establishment and implementation of criminal justice. It defines the actions and omissions that are considered illegal and punishable, and penalties and other measures taken against authors of criminal offenses. First continuous improvement of legislation, and its adaptation in accordance with European Union directives, are important elements for a more efficient effort to reduce crime. Second: the role of institutions of execution of sentence, must constantly being strengthened, since they are the last link but important of criminal justice system. If this execution is not performed or not performed at all in the proper way then the entire justice system work for the punishment of the author and rehabilitation of the convicted is dismissed. But always for an execution as right as possible should be considered certain conditions in which the victim is, to give an individualized sentence and in compliance with the convicted.

\section{References}

Code of Criminal Procedure of the Republic of Albania

Criminal Code of the Republic of Albania

Elezi, I., and Hysi, V., "Criminal politics", PEGI, Tirana, 2006

I. Elezi, "The Criminal Law Special Part ", Tirana 2005

Islami H., Hoxha A., Panda I., "Criminal Procedure", Editions Morava, Tirana 2010

Kurti, S. (2015). The Accessory Penalties for Individuals and their Execution According to the Albanian Legislation. Academic Journal of 
Interdisciplinary Studies, 2015.

Law Nr Nr.8331, dated 21.4.1998 "For the execution of criminal decisions"

Law Nr.8328, dated 16.4.1998 "Rights and treatment of prisoners and detainees"

Nj. Shtino "Forensic Psychiatry", 2005,

Prof. Dr. I.Elezi, Prof. S. Kaçupi. Prof. Ass.Dr M.Haxhia, Commentary of the Criminal Code (the general part) Tirana 2009 (updated and

supplemented with additions and changes made to legal reforms of the years 2001, 2003, 2004, 2008 as well as case law)

Prof.Dr. I. Elezi, " Criminal Law of the Republic of Albania ", Tirana, 2002

Prof.Dr. V. Hysi "Introduction to criminology and penology "Tirana 2000

The Constitution of the Republic of Albania

United Nations Rules for the Protection of Minors, who are deprived of liberty, Adopted by General Assembly resolution 45/113, dated December 14, 1990

V. Hysi "Criminology ", Tirana, 2006,

www.thiennhien.net

www2.ohchr.org

highered.mcgraw-hill.com

arkiva.mfa.gov.al

www.euralius.eu 